\title{
NIEUWE EXTERNE INVLOEDEN
}

\author{
door Prof. Mr.J. Th. Degenkamp
}

\section{Inleiding}

Thema van dit MAB-nummer is ,de vermaatschappelijking van de onderneming". In 1965 verscheen onder dezelfde titel het proefschrift van J. Valkhoff's leerling: S. Bergsma. Een van de (vele) verdiensten van Valkhoff is geweest dat hij als een van de eersten in Nederland gewezen heeft op de nauwe samenhang tussen de ontwikkeling van de maatschappij en die van het recht. Met recht kan worden gesteld dat Valkhoff de Nederlandse juristen bekend heeft gemaakt met de term en - belangrijker nog - met het verschijnsel: vermaatschappelijking.

Bergsma schrijft: „Erkend moet worden dat het ondernemingsbeleid bepaald wordt in interdependentie met een groot aantal andere beleidsbronnen buiten de onderneming gelegen. Omdat deze beïnvloeding van de onderneming gericht is op het doen overeenstemmen van het ondernemingsbeleid met de maatschap. pelijke doelstellingen kan het hierboven beschreven proces het best gekarakteriseerd worden als de vermaatschappelijking van de onderneming" (Bergsma 1965, pag. 163).

Mij is gevraagd enkele opmerkingen te maken over nieuwe externe invloeden, waarbij ,externe instanties” als overheid, werkgevers- en werknemers-organisaties buiten beschouwing kunnen blijven omdat zij door anderen zullen worden behandeld. Uit het navolgende zal blijken dat na deze eliminatie nog voldoende externe beïnvloeders overblijven.

In het navolgende zal - na enig terminologisch voorwerk - getracht worden enkele m.i. belangrijke ontwikkelingen te schetsen.

\section{Onderneming en rechtsvorm van de onderneming}

De term "onderneming" komt zowel voor in de omgangstaal, in de taal van de economische wetenschap, in de taal van het recht als in de taal van de rechtswetenschap. Het door elkaar halen van deze talen is niet aan te bevelen, toch ge schiedt dit m.i. (te) vaak. „Poolse Landdag”-discussies over het „wezen” en het "doel" van de onderneming zijn hiervan het gevolg geweest, discussies die n.m.m. alles met politiek en weinig met wetenschap te maken hebben.

In het kader van dit artikel wordt onder onderneming verstaan het organisa. torisch verband waarin de ondernemings-activiteiten worden gerealiseerd voor rekening van de ondernemer(s).

Van ondernemings activiteiten is sprake als arbeid of subjectieve vermogens. rechten worden aangewend voor de productie van goederen en diensten ter deelname aan het economisch verkeer. Opmerkenswaard is dat een onderscheid wordt gemaakt tussen subjectieve vermogensrechten (de eigendom van grond. stoffen, gebouwen, vorderingen etc.) en arbeid. Dit is een contingente kwestie. In ons rechtsstelsel is de ,arbeidsinbrenger” geen eigenaar van het door hem ingebrachte ,arbeids vermogen”. De grondstoffen-leverancier levert ook juridisch, de 
betalende debiteur levert (de eigendom van) geld, maar de "medewerker” levert juridisch niets, zij/hij presteert „slechts” volgens ons rechtsstelsel. Geld- en goederen-inbreng worden in ons rechtsstelsel gekwalificeerd als inbreng van subjec. tieve rechten; ten aanzien van de factor arbeid, de werk-,,gevers", bestaat juridisch gezien een bijzondere „huur”-positie!

In de omschrijving van onderneming ligt de nadruk op de activiteit: onderne. men, niet op het doel of de doelen waarmee dit gebeurt.

De subjectieve vermogensrechten die worden aangewend worden tesamen het ondernemingsvermogen in ruime zin genoemd. Is sprake van directe toere. kening van resultaten (waarbij deze toerekening moet worden geïnterpreteerd als een juridische en niet als een economische!) aan vermogensbestanddelen, dan is sprake van eigen of (met een zeer verwarringwekkende term) risicodragend ver. mogen. Is sprake van een niet-directe toerekening van resultaten aan vermogens. bestanddelen, dan is sprake van vreemd vermogen. De term „,risico dragend" ver. mogen wekt zeer licht verwarring. Immers, ook het vreemd vermogen draagt b.v. het solvabiliteits-risico (alweer, in juridische zin). Dat ook de ,arbeidsvermogen”. verschaffers risico's lopen behoeft hopelijk nauwelijks betoog.

Bij het ondernemen zijn veel rechtssubjecten betrokken. Rechtssubjecten zijn natuurlijke personen en rechtspersonen. Rechtspersonen zijn verzamelingen van natuurlijke en rechtspersonen die door het recht als persoon worden erkend. Het zijn juridische constructies.

Betrokken zijn in de eerste plaats de geld., goederen-en arbeid-verschaffers. Be. trokken kunnen voorts worden geacht degenen die aan de in- en de output-kant van de onderneming staan: leveranciers, afnemers. In nog ruimer verband kun nen betrokkenen worden genoemd degenen die externe effecten van het ondernemen ervaren: omwonenden, maar ook b.v. tuinders aan de voet van de Rijn, en ook weer vertegenwoordigers van betrokkenen.

Het ondernemen gaat gepaard met financiële risico's. „Ondernemers” worden genoemd degenen aan wie deze financiële risico's direct worden toegerekend. In het (relatief vaak) voorkomende geval dat de rechtsvorm van de onderneming rechtspersoonlijkheid impliceert - zoals b.v. bij de NV en de BV het geval is - is de rechtspersoon de ondernemer. Directe toerekening aan de rechtspersoon sluit indirecte gevolgen voor b.v. aandeelhouders niet uit; ditzelfde geldt voor certificaathouders en ook voor werknemers met winstdelingsrechten.

De op deze wijze omschreven begrippen „ondernemen”, „onderneming” en „ondernemer" zijn neutraal ten aanzien van de rechtsvorm van de onderneming.

Het Nederlandse recht geeft rechtssubjecten die wat willen ondernemen een ruime keuze: eenmanszaak, vennootschap onder firma, maatschap, BV, NV, ver. eniging, stichting etc.!

Deze rechtsvormen geven juridisch vorm aan de onderneming als sociaal-economische eenheid. Dit juridisch vorm geven kan impliceren het verlenen van rechtspersoonlijkheid (NV en BV o.a.), noodzakelijk is dit echter niet (maatschap, vennootschap onder firma). De juridische vormgeving kan v.w.b. de interne structuur een dwingend karakter hebben, kan echter ook vooral aanvullend rechtelijke regels bevatten; de regeling kan zeer complex zijn, kan echter ook zeer eenvoudig en zeer summier zijn. Een complexe dwingende structuur geldt b.v. voor een NV of BV waarop de structuurregeling van Boek 2 van het Burgerlijk Wetboek van toepassing is; een eenvoudige aanvullend rechtelijke regeling geldt voor de ven. 
nootschap onder firma (uiteraard geldt deze kenschets in beginsel!)

Juridische vormgeving van de onderneming geschiedt doordat het recht aan economische functies juridische variabelen (verplichtingen en bevoegdheden) toevoegt. Welke verzameling bevoegdheden en verplichtingen, c.q. de hiermee corresponderende ,onderworpenheden" en aanspraken, aan bepaalde groepen economische functie-dragers worden toebedeeld, wordt bepaald door de bestaande politieke machtsverhoudingen. De NV en BV zijn niet „wezenlijk” kapitaal-associaties; het is een contingente kwestie dat de positie van de geld. en goederenvermogensverschaffers (nog?) significant verschilt van die van de arbeidsvermo. gensverschaffers. Toch lijkt het niet onhandig een onderscheid te maken tussen rechtsvormen van de onderneming waarbij het lot van de rechtsvorm samenhangt met het persoonlijk lot van bepaalde groepen participanten en die waarbij dit niet zozeer het geval is. Of de termen ,personen " en „kapitaal-associatie” daar. bij de meest gelukkige zijn, kan worden betwijfeld. Het door mij voorgestelde wijkt af van het klassieke juristentaal-gebruik. Het Handboek voor de Naamloze en de Besloten Vennootschap (Van der Heijden-Van der Grinten 1976, pag. 40) noemt de NV en BV kapitaalvennootschappen; erkend wordt dat in de $\mathrm{zg}$. structuurvennootschappen de ondernemingsraad , in zekere zin" orgaan is (pag. 63). Hetzelfde kan m.i. gesteld worden ten aanzien van de ondernemingsraad in ,gewone" ondernemingen die in besloten of naamloos-vennootschappelijke jas zijn gestoken. Ook in deze vennootschappen is in bepaalde gevallen de medewerking van de ondernemingsraad noodzakelijke voorwaarde voor het totstandkomen van een besluit dat door het recht wordt gequalificeerd als een besluit van de rechtspersoon; in zulke gevallen fungeert de ondernemingsraad derhalve als orgaan.

Waarom deze wat lange inleiding over onderneming en rechtsvorm? Mijn doel was aan te geven dat het maken van onderscheid tussen economische en juridi. sche termen noodzakelijk en zinvol is, dat naamgeving van verschijnselen andere dan beschrijvende effecten kan hebben, dat de bestaande bevoegdheden en ver. plichtingen-verdeling binnen de onderneming toevallig (contingent) en niet „na. tuurnoodzakelijk" is en dat als gevolg daarvan datgene wat gisteren extern was vandaag of morgen intern kan zijn.

\section{„Nieuw", „extern" en ,invloed"}

Nieuw is wat "nieuw" genoemd wordt. Met betrekking tot de nieuwheid van ontwikkelingen lijken de zestiger jaren een trendbreuk te hebben opgeleverd.

„Invloed" levert iets meer problemen op. Helmers c.s. (Helmers 1975, pag. 65) definiëren (politieke) macht als het vermogen van actoren (personen, groepen of instellingen) om een samenstel van alternatieve waardetoedelingen voor de le. den van een systeem of delen daarvan (ten dele) vast te leggen of te veranderen en (politieke) invloed als het vermogen van actoren de uitkomsten van het toe. delingsproces (ten dele) te bepalen. In de door Helmers c.s. voorgestelde definitie is het ontbreken van een sanctie-mogelijkheid definiërend kenmerk voor invloed.

In het kader van deze tekst lijkt het handiger juist wel de mogelijkheid van in. schakeling van de juridische handhavings-machinerie als kenmerk van invloed op te nemen. Het kunnen inschakelen van de juridische handhavings-organisatie, het in rechte door burgers (= niet overheden) in actie kunnen komen, is kenmerk van 
subjectieve rechten. Wie een subjectief recht heeft, heeft een actie tot handhaving. Deze aan subjectieve rechten gekoppelde acties worden in de literatuur ,afgeleide acties" genoemd (Van Buuren 1978, pag. 7). Ons recht kent echter ook de mogelijkheid in actie te komen niet op grond van een subjectief recht. Deze acties worden ,zelfstandige acties” genoemd. Van Buuren geeft de volgende omschrijving: „Zelfstandige acties worden gecreëerd om rechtsregels te sanctioneren, die zich niet laten formuleren als rechten of als verplichtingen van de een tegenover de ander (in welk geval uit die rechtsregels immers al subjectieve rech. ten zouden voortvloeien) maar bij welker functioneren de belangen van meerdere rechtssubjecten tegelijk betrokken zijn of algemene belangen een rol spelen. Om naleving van die rechtsregels te waarborgen, kan de wetgever dan aan (be. paalde) belanghebbenden of belangenvertegenwoordigers een actie toekennen" (Van Buuren, 1978, pag. 8).

Voorgesteld wordt nu van (juridische) invloed te spreken als sprake is van de mogelijkheid van het instellen van een zelfstandige actie.

Zelfstandige acties komen in het privaatrecht - en in het bijzonder in het ondernemingsrecht - voor, nemen in belangrijkheid toe en zullen vermoedelijk in de toekomst in belangrijkheid blijven toenemen.

In het navolgende zullen enkele voorbeelden worden gegeven van de moge. lijkheid om als externe instantie of als extern persoon in actie te komen. Externe rechtssubjecten zijn daarbij dan subjecten die niet op grond van een lidmaat. schapsrelatie of een contractuele relatie binnen de onderneming functioneren. Op grond van het feit dat de komende beroepsmogelijkheid van de onderne. mingsraad tegen besluiten van de ondernemer bij de Ondernemingskamer van het Hof te Amsterdam een interne actie is en de actie terzake van algemeen verbindend verklaarde bepalingen van collectieve arbeidsovereenkomsten en loon. regelingen door vakbonden kan worden ingesteld, worden deze twee acties - om. dat zij buiten de context van dit artikel vallen - niet behandeld (zie Bakels 1966).

\section{Het vragen van vernietiging van besluiten van organen van rechtspersonen}

Op grond van artikel 11 lid 2 Boek 2 BW hebben naast de leden, aandeelhouders en bestuurders, ook ,andere belanghebbenden" de bevoegdheid vernietiging te vragen bij rechterlijk vonnis van besluiten van de algemene vergadering van een vereniging, NV of BV. Deze clubs waaronder de andere belanghebbenden heb. ben deze bevoegdheid onder voorwaarde dat zij een „redelijk belang” hebben bij de naleving van de wettelijke of statutaire bepalingen of van de goede trouw. Artikel 13 Boek 2 BW verklaart deze regeling van overeenkomstige toepassing op besluiten genomen door andere organen, ook van andere rechtspersonen dan de hiervoor genoemde. Bevoegdheidsoverschrijdingen leveren in deze laatste geval. len zelfs nietigheid in plaats van vernietigbaarheid op!

Van Schilfgaarde wijst als mogelijke belanghebbenden aan: werknemers, winstgerechtigenden en crediteuren (Van Schilfgaarde 1976, pag. 157). De eerste twee groepen zijn op grond van de hiervoor gemaakte terminologische afspraken ,internen”, de laatste groep is „extern”. Als mogelijke externen worden voorts door Van Schilfgaarde genoemd: de personen wier belangen door een vereniging of stichting worden gediend, de Consumentenbond, de Vereniging Effectenbe-

$m a b$ blz 424 
scherming en vakverenigingen. Wie onder deze belanghebbenden valt is voor. alsnog onzeker omdat ten aanzien van deze groepen nog geen jurisprudentie voorhanden is.

\section{Het vragen van correctie van de jaarrekening}

Artikel 337 lid 1 Boek 2 BW bepaalt dat ,iedere belanghebbende" die van oordeel is dat de jaarrekening van een rechtspersoon niet in overeenstemming is met de jaarrekeningvoorschriften, de bevoegdheid heeft de Ondernemingskamer te vragen bij rechterlijk bevel wijziging te gelasten.

Bij de totstandkoming van deze regeling is ampel gediscussieerd over het begrip „,belanghebbende”. De Kamers hebben geprobeerd een nadere omschrijving of een opsomming aan de minister te ontlokken, dit is maar gedeeltelijk gelukt. Pas in het eindverslag Eerste Kamer wordt een zekere aanduiding door de minister gegeven, formeel bindt deze omschrijving de rechter echter niet. Gesteld wordt dat aandeelhouders en certificaathouders zeker belanghebbenden zijn. Crediteuren, werknemers en hun organisaties zijn - naar het inzicht van de minister - onder omstandigheden belanghebbenden in de zin van dit artikel. De minister wilde de uitleg van "belanghebbenden” aan de rechter overlaten en Van IJsselmuiden (Rechtspersonen, pag. 337.4) verklaart zich hiermee akkoord.

Wie belanghebbende kunnen zijn - aldus Van IJsselmuiden - hangt af van de aard van de onderneming, van haar omvang en van haar plaats in de maatschappij. Maar - zo vervolgt hij - "het gaat niet om wie belanghebbenden kunnen zijn, doch om wie het in een bepaalde situatie zijn; en of dat het geval is, dient de rechter te beslissen”. Een opmerkelijke „redenering”! Gesteld wordt in de eerste plaats dat de kwaliteit: belanghebbende een feitelijk karakter heeft en vervolgens dat de rechter hierover dient te beslissen. Ook hier geldt weer belanghebbende is de. gene die „belanghebbende” wordt genoemd. Dat benoemen kan gebeuren door de rechter, maar ook b.v. door de wetgever die zeer wel in staat is b.v. een nadere omschrijving of een opsomming te geven. Dat daarna de rechter - gegeven de bestaande b.v. in een wet geformuleerde regel - een beslissing moet en kan nemen, betekent nièt dat alleen de rechter de betekenis van bepaalde termen kan vaststellen. Het finale toepassen van rechtsregels in geschillen is wel in handen van rechters, maar de regels zelf kunnen daarna eventueel weer worden gemodificeerd door de club van wetgevers. Opmerkelijk is dus dat vanuit de Kamers wel gevraagd is naar een (niet bindende) interpretatie door de minister, dat de Kamers echter niet zelf het heft (mede) in hand hebben genomen en zelf een in. terpretatief artikellid hebben toegevoegd. Betekenisvaststelling door de rechter heeft wel een onvermijdelijk en een finaal, maar behoeft geen ongelimiteerd karakter te hebben!

Met betrekking tot dit artikel bestaat al enige jurisprudentie. In de procedure Voedingsbonden NVV en NKV tegen Homburg BV besliste de Ondernemingskamer dat deze bonden een ,rechtstreeks eigen belang hebben bij de jaarrekening” (uitspraak 14.4.1977, NJ 1978, 442).

Zoals wellicht bekend is is de Stichting SOBI (vroeger: Stichting voor Sociaal Aandeelhouderschap, nu: Stichting Onderzoek Bedrijfs Informatie) uitermate actief op het gebied van jaarrekeningen. Op 26-5.1977 besliste de Ondernemingskamer dat SOBI belanghebbende was in de zin van artikel 337 alhoewel de stich. 
ting op het moment van het indienen van de inleidende dagvaarding nog geen aandeelhouder was, maar op dat tijdstip overwoog een aandeel te kopen en dat voornemen had uitgevoerd. SOBI had zich dus op tijd "geïnternaliseerd".

Ook KSH is voorwerp van SOBI-eus onderzoek geworden; in een door SOBI aangespannen procedure voerde $\mathrm{KSH}$ aan dat de aanschaf van ,een aandeeltje KSH” pour besoin de la cause was geschied. KSH stelde: „eisers beschouwen en gedragen zich als een soort particulier procureur-generaal en bemoeien zich met alle jaarrekeningen waarvan zij menen dat daarop iets valt aan te merken". KSH achtte deze situatie ongewenst. In verband met de gevorderde dwangsommen werd opgemerkt dat toewijzing zou betekenen „dat het lonend wordt allerlei jaarrekeningen aan de kaak te stellen waarbij men zelf geen enkel financieel of ander belang heeft".

Het antwoord van de Ondernemingskamer is kort en duidelijk: „Nu ten processe vaststaat dat eisers aandeelhouders van $\mathrm{KSH}$ zijn geworden, kan in het mid. den blijven waarom zij tot verwerving van een aandeel KSH zijn overgegaan. De beweegredenen die eisers hebben gehad om een aandeel te verwerven missen te dezen betekenis"!

De vraag of SOBI-seul belanghebbende is in de zin van art. 337 is nog niet beantwoord. Ditzelfde geldt voor b.v. de Vereniging Effectenbescherming, de Consumentenbond en het NIvRA; deze ,collectieven" zijn nog niet in actie gekomen. Volgens Van IJsselmuiden is belanghebbende ook degene wiens beloning als derde mede afhankelijk is van winst, bruto-winst of omzet (Rechtspersonen, 337-7).

\section{Het wetsontwerp misleidende reclame}

Op 18.9.1975 is bij de Tweede Kamer ingediend een ontwerp van wet houdende regelen omtrent de privaatrechtelijke bescherming tegen misleidende reclame (w.o. 13611).

Belangrijke bepaling in dit wetsontwerp is art. $1416 \mathrm{c}$ lid $2 \mathrm{BW}$ : de actie tot verbod en rectificatie van misleidende reclame komt mede toe aan ,rechtspersonen met volledige rechtsbevoegdheid, die ten doel hebben de behartiging van belan. gen van ondernemers of van eindgebruikers van niet voor een beroep of bedrijf bestemde goederen of diensten". Deze - wat moeizame - omschrijving heeft bij de behandeling in de Tweede Kamer al wat problemen opgeleverd. Van SGP-zij. de werd gevraagd hoe het zat met de organisaties van eindgebruikers van wel voor een beroep of bedrijf bestemde goederen, die geen ondernemer zijn. Het antwoord van de bewindslieden hierop was dat deze wel ondernemer zijn en als ondernemers onder 1416c lid 2 BW vallen. Opmerkelijk is dat in de Memorie van Antwoord (pag. 26) wordt gesteld dat het ,,minder voor de hand ligt" organisaties van beroepsbeoefenaren deze actie-mogelijkheid tegen misleidende reclame te geven. De argumentatie is opmerkelijk: beroepsbeoefenaren maken „minder veelvuldig" reclame en de beroepsorganisaties hebben geen behoefte geuit. Terecht worden door D. W. F. Verkade ten aanzien van dit punt zeer kritische opmerkingen gemaakt (Nederlands Juristenblad, 9-6-1979, pag. 462). Wordt dit wetsontwerp wet dan zullen ondernemers- en consumenten organisaties een zelfstandige actie krijgen tegen misleidende reclame. 


\section{Slotopmerking}

In het voorgaande zijn enkele opmerkingen gemaakt over het verschijnsel zelfstandige actie in het privaatrecht. Deze zelfstandige acties geven burgers en "collectieven" de mogelijkheid te ageren tegen door hen onwenselijk geachte ver. schijnselen. Te verwachten valt dat zowel de verzameling „aanvechtbare verschijnselen” als de verzameling „zelfstandige-actie groepen” in de toekomst in betekenis en in omvang zullen toenemen.

\section{Literatuur:}

Bakels 1966: H. L. Bakels: Het arbeidsrecht en het sociaal economisch recht. Enige opmerkingen over de „zelf. standige actie" van privaatrechtelijke organisaties. In: Hedendaags arbeidsrecht (Levenbach-bundel), Alphen aan de Rijn. 1966.

Bergsma 1965: S. Bergsma: De vermaatschappelijking van de onderneming, Deventer 1965.

Van Buuren 1978: P. J. J. van Buuren: Kringen van belanghebbenden; In het bijzonder in procedures tegen de overheid, Deventer 1978.

Helmers 1975: H. M. Helmers c.s.: Graven naar macht, Amsterdam 1975.

Van der Heijden.Van der Grinten 1976: Handboek voor de NV en BV, Zwolle 1976.

Rechtspersonen: Losbladig Commentaar, Kluwer-Deventer.

Van Schilfgaarde 1976: P. van Schilfgaarde: Rechtspersonen, Algemeen Deel, Deventer 1976. 